\title{
Diplomatski sporovi oko transbalkanskih željezničkih projekata od 1900. do 1912. u kontekstu albanskoga pitanja
}

\author{
GAZMEND RIZAJ \\ Universiteti i Prishtinës, Fakulteti Filozofik - Departamenti i Historisë, Repu- \\ blika e Kosovës \\ Priština, Kosovo \\ gazmend.rizaj@uni-pr.edu
}

\begin{abstract}
Članak donosi pogled iz diplomatskoga ugla na suparništvo i nesuglasice velikih sila i novih balkanskih država u vezi s projektima transbalkanskih željeznica. Temelji se uglavnom na arhivskoj građi diplomatske provenijencije. Od 1900. do 1912. razvio se diplomatski diskurs o balkanskim željeznicama, prije svega između Austro-Ugarske i Srbije (1906. - 1912.). Međutim, ti će projekti ostati samo na papiru zbog političkih prevrata na Balkanu od 1908. do 1912., a osobito zbog diplomatske krize koja je 1912. zavladala između Austro-Ugarske i Srbije zbog izlaska Srbije na Jadran preko albanskoga primorja.
\end{abstract}

Ključne riječi: Austro-Ugarska; balkanski željeznički projekti; velike sile; Jadransko more; Šenđin; Srbija

Opće gospodarske prilike na Balkanu krajem XIX. i početkom XX. stoljeća

Industrijska revolucija u Europi i ujedinjenje Italije i Njemačke između 1861. i 1871. označili su uspon velikih industrijskih sila u Europi i početak imperijalizma. Bilo je to razdoblje ekonomske i političke ekspanzije velikih sila, njihove borbe za tržišta i kolonije. Po završetku „podjele svijeta” njihova se borba nastavila u stvaranju interesnih sfera. Antagonizmi i utrka velikih sila za uspostavu ekonomskoga i političkoga utjecaja u Osmanskom Carstvu osobito se pojačavaju nakon ujedinjenja Njemačke 1871. i njezina ubrzanoga gospodarskog i vojnog razvitka. Posljedično, tijekom druge polovine XIX. i početkom XX. stoljeća velike europske sile raspoređuju se u dva suparnička bloka, Trojni savez i Trojnu antantu, što se odrazilo i u njihovoj balkanskoj politici. U prvim desetljećima XX. stoljeća velike sile potpisale su brojne tajne ugovore o podjeli interesnih sfera od Indije pa sve do Balkanskoga poluotoka. 
No još početkom istoga stoljeća u tu podjelu uključuju se i nove balkanske države, s glavnim ciljem što bržega razbijanja Osmanskoga Carstva na Balkanu i širenja granica vlastitih država.

Razvoj kapitalističkih odnosa u novim balkanskim državama poticao je društveno raslojavanje, odnosno rast moći buržoazije, vojske, birokracije i vladajućih dinastija. Taj razvojni put popraćen je usponom nacionalizma, šovinizma i megalomanije. Megalomanske pretenzije novih balkanskih država nisu bile slučajne. One su u drugoj polovini XIX. i prvom desetljeću XX. stoljeća doživjele relativno brz gospodarski i društveni razvitak. Trgovinski promet sa zapadnom i srednjom Europom i brzi prirast stanovništva utjecali su na nacionalni prosperitet tih zemalja. Do tridesetih godina XX. stoljeća obim vanjske trgovine novih balkanskih država bio je pet puta veći. U takvim okolnostima osnivane su nacionalne banke tih zemalja, što je otvorilo vrata prodoru inozemnoga financijskoga kapitala, posebice preko državnih zajmova. Početkom XX. stoljeća mlade balkanske države ušle su u fazu postupnoga rasta industrije. U Rumunjskoj i Grčkoj postojala je željeznička mreža koja je premašivala 1500 km, a u Srbiji i Bugarskoj bilo je preko 500 km željezničke pruge. ${ }^{1}$ Sveukupni gospodarski razvitak rezultirao je povećanim potrebama balkanskih država za tržištima i za punom ekonomskom i političkom neovisnošću. Za postizanje tih ciljeva bilo je potrebno osnažiti se i u vojnom smislu. Ubrzo je počelo opskrbljivanje oružjem, koje se uglavnom kupovalo od zapadnih proizvođača. Bugarska je 1904. s Francuskom potpisala nekoliko ugovora za opskrbu topništva, a s Njemačkom je ugovorena opskrba streljivom. Grčka je 1905. počela kupovati puške iz Austrije, a topove iz Francuske. S druge strane, francuski i njemački kapital bio je u velikom natjecanju za opskrbu Osmanskoga Carstva vojnim materijalom. Tako su sve balkanske države povećale svoj vojni budžet. Na vojni budžet Srbije otpadalo je $22 \%$ od ukupne državne potrošnje, na bugarski vojni budžet $24 \%$, na rumunjski $18,7 \%$, a na grčki $22,7 \%{ }^{2}$

U takvim okolnostima mlade balkanske države nastoje dobiti što povoljnije uvjete za svoj gospodarski razvitak. Shodno tome, tijekom posljednjih desetljeća XIX. i početkom XX. stoljeća počinje vrlo snažno uvezivanje gospodarskih i strateških pitanja. U kontekstu Balkana to će uvezivanje dobiti još specifičnije značenje jer će doći do sudara interesa ne samo velikih sila nego i novih balkanskih država. Ideje i projekte za izgradnju balkanskih željeznica u prvom desetljeću XX. stoljeća izlažu Austro-Ugarska, Italija, Srbija, Crna Gora,

\footnotetext{
1 Jelavich na temelju statističkih bilješki autora N. Spulbera, I. Barenda i G. Rankija naglašava: „Prva grčka linija bila je dionica pruge duga $9 \mathrm{~km}$ od Atene do Pireja, izgrađena 1867. - 1869.; do 1914. zemlja je imala 2196 km tračnica. Prva rumunjska željeznica krenula je od Bukurešta do dunavske luke Giurgiu; do 1914. mreža se povećala na 3754 km. Do toga vremena Srbija je imala $1567 \mathrm{~km}$ željeznice, a Bugarska $2227 \mathrm{~km}$. [...] Sve ove pruge, iako su ih gradile strane privatne tvrtke, nacionalizirane su, u Rumunjskoj 1888., u Srbiji između 1889. i 1892., u Bugarskoj 1885. i u Grčkoj od samoga početka" (Ch. JELAVICH, B. JELAVICH, Themelimi i shteteve kombëtare të Ballkanit, 184).

2 ЂОРЂЕВИЋ, „Србија и Балкан”, 207-210; чУБРИЛОВИЋ, Историја политичке мисли, 201-206.
} 
Bugarska i Grčka, ali će u to pitanje osim Osmanskoga Carstva ${ }^{3}$ biti upletene i druge europske sile.

\section{Austrougarska željeznička politika}

U drugoj polovini XIX. stoljeća i do početka Prvoga svjetskog rata AustroUgarska Monarhija bila je glavna gospodarska sila na Balkanskom poluotoku. Taj primat iskoristila je na planu izgradnje željeznica, proširujući postupno svoj ekonomski i politički utjecaj u jugoistočnoj Europi. Nove balkanske države, sa slabim gospodarstvima, nisu mogle same izgraditi željeznice, a bile su svjesne da su upravo one glavna arterija njihova brzoga gospodarskog i političkog napretka.

Kako navode Charles i Barbara Jelavich, sredinom XIX. stoljeća „sve balkanske zemlje imale su strast za izgradnju željeznica". ${ }^{4}$ Upravo će tu okolnost dobro iskoristiti Dunavska Monarhija i gradnjom transbalkanskih željeznica proširiti svoj ekonomski utjecaj na Balkanu, čak i na udaljena područja koja su ostala relativno netaknuta od britanskih i francuskih industrijskih i komercijalnih kompanija. Beč je 1868., samo godinu dana nakon osnivanja Dvojne Monarhije, uspio od Visoke porte dobiti koncesiju za realizaciju vrlo ambicioznoga plana za to vrijeme, tj. za izgradnju željezničke pruge na liniji Istanbul Adrianopol (Drinopolje/Edirne) - Plovdiv - Sofija - Niš - Beograd sve do austrougarske granice. Gradnja je započela 1872., ali je privremeno obustavljena zbog ustanaka i ratova na većem dijelu Balkanskoga poluotoka tijekom „istočne krize" od 1875. do 1878. godine. Radovi su po završetku krize nastavljeni, a željeznička pruga koja povezuje Istanbul i Beč završena je 1888. godine. ${ }^{5}$

Austro-Ugarska je na Berlinskom kongresu kao jedan od uvjeta za priznavanje neovisnosti Srbije zahtijevala od srpske vlade da se obveže angažirati austrijsku tvrtku za izgradnju željezničke pruge od Beograda do osmanske granice makedonskih pokrajina. Srbija bi također bila dužna surađivati s Austrijancima u izgradnji sljedeće željeznice do Bugarske i Osmanskoga Carstva. Još jednim austrijskim uvjetom predviđeno je da će Srbija prihvatiti AustroUgarsku kao najpoželjniju „trgovačku zemlju” za planirani režim plovidbe Dunavom. Iako ti uvjeti nisu bili povoljni za Srbiju, njezina vlada bila ih je primorana prihvatiti. ${ }^{6}$ Dakle, političkom dogovoru prethodila su dva sporazuma, Sporazum o željeznicama i Sporazum o trgovini, sklopljena u travnju 1881. godine. Pod sličnim uvjetima kao za Srbiju Beč je obvezao i rumunjsku vladu

\footnotetext{
3 U posljednjim godinama vladavine sultana Abdula Hamida II. (1876. - 1909.) Osmansko Carstvo trostruko je povećalo gradnju željeznica u odnosu na godine kada je sultan došao na prijestolje. Tako je 1907./1908. željeznička mreža Osmanskoga Carstva obuhvaćala 5883 km, a to se odrazilo i u desetostrukom povećanju državnih prihoda od željezničkih aktivnosti (S. SHAW, E. SHAW, Historia e Perandorisë Osmane, 282).

4 Ch. JELAVICH, B. JELAVICH, Themelimi i shteteve kombëtare të Ballkanit, 183.

5 Isto.

6 GLENNY, The Balkans, 149-150.
} 
da prihvati trgovinske sporazume i angažiranje austrijskih tvrtki za izgradnju rumunjskih željeznica uz vrlo povoljne uvjete. ${ }^{7}$ Slično kao u slučaju Rumunjske i Srbije, Berlinski je ugovor člancima 10. i 11. i Bugarsku uveo u tzv. željezničko pitanje, koje će u bugarskom kontekstu trajati najmanje tri desetljeća. Bugarska je bila obvezna financirati nekoliko projekata izgradnje željeznica i podnijeti ponude stranim konzorcijima. Austrijski barun Hirsch dobio je pravo produžiti željezničku liniju Orient Express kroz Bugarsku i povezati ju s prugom koja je već bila u izgradnji u istočnoj Rumeliji. U pitanju bugarskih željeznica imale su udjela i britanske tvrtke: tvrtka Barclay Brothers kupila je staru i neiskorištenu prugu Ruse - Varna za izgradnju priključnoga dijela pruge Istanbul - Beč koji bi prolazio preko bugarskoga teritorija. U tim okolnostima Rusija, koja je imala svoje planove o kontroli suvereniteta Bugarske, nije ostala postrani, nego je tražila od Bugarske financiranje izgradnje željezničke pruge od grada Ruse duž Dunava do Sofije, koju je smatrala od velikoga strateškog značenja. Rusi su čak željeli da se ta pruga izgradi prije one baruna Hirscha. No bugarski princ Aleksandar Battenberg i bugarske političke stranke smatrali su izgradnju Orient Expressa važnijom za zemlju u gospodarskom pogledu. Pitanje željezničkih pruga još je više produbilo nesuglasice Bugara i Rusa, posebno između bugarskoga princa i ruskih careva, što je 1886. rezultiralo abdikacijom princa Battenberga. ${ }^{8}$

Kako je Bosna i Hercegovina od 1878. bila pod austrougarskom okupacijom, a pozivajući se na odredbe Berlinskoga kongresa, Beč je 1900. pokrenuo pitanje izgradnje bosanske željeznice od Uvca ${ }^{9}$ do Mitrovice na Kosovu, ali je od toga morao odustati kada je ruski veleposlanik u Beču skrenuo pozornost na to da je takva namjera u suprotnosti s austro-ruskim tajnim sporazumom iz 1897. o očuvanju statusa quo na Balkanu. Beč se svojem planu ponovo vraća u prosincu 1902., kada u tu svrhu od njemačke vlade traži diplomatsku potporu kod Porte. Međutim, njemački kancelar Bernhard von Bülow savjetuje ministra vanjskih poslova Austro-Ugarske grofa Agenora Romualda Gołuchowskog da napusti tu zamisao zbog nepovoljne situacije u Makedoniji, „no, ostane li kod svoje namjere, neka se prije svega sporazumi s Rusijom, kako bi ona primirila Srbiju, Crnu Goru i Bugarsku, koje će se bez sumnje protiviti tome planu".10 Ministar vanjskih poslova carske Rusije grof Vladimir Nikolajevič Lamsdorf osobno moli austrijskoga cara Franju Josipa i grofa Gołuchowskog neka napuste taj plan jer ruska vlada ostaje pri mišljenju koje je dala još 1900., na što Austro-Ugarska na kraju pristaje. ${ }^{11}$

7 Isto, 150.

8 DZHALEVA-CHOKOVA, „Balkans Railways Development”; GLENNY, The Balkans, 172; Ch. JELAVICH, B. JELAVICH, Themelimi i shteteve kombëtare të Ballkanit, 183.

9 Uvac, naselje u istočnom dijelu Bosne na granici sa Srbijom. Bio je jedna od dviju postaja Bosanske istočne željeznice izgrađene od Sarajeva do Uvca i Vardišta za vrijeme austrougarske vladavine u Bosni i Hercegovini. Izgradnja pruge započela je 1903. („Uvac, Rudo”).

${ }_{10}$ ŠIŠIĆ, Predratna politika Italije, 56.

11 Isto. 
Širenje austrijske željeznice dalo je veliki poticaj austrougarskom gospodarstvu. Od 1867. do 1907. austrougarska se željeznička mreža udesetostručila. ${ }^{12}$

Projekti za balkansku transverzalnu željeznicu Dunav - Jadran

Od svih balkanskih država jedino Srbija nije imala izlaz na more, pa je u prva dva desetljeća XX. stoljeća izlazak Srbije na Jadran postao istinska opsesija srpskih političkih vođa. Kako bi dobila trgovački izlaz na Jadransko more, srpska vlada istupila je 1906. s projektom izgradnje pruge na balkanskoj transverzali Niš - Kosovo - Šenđin (San Giovanni di Medua), koja bi povezala Dunav s Jadranom. Ideja o izgradnji željeznice Dunav - Jadran pojavila se prilično rano u srpskim političkim krugovima. Datira još iz 1896. godine. ${ }^{13}$ Ponovo je aktualizirana 1906., upravo u vrijeme carinskoga rata između Austro-Ugarske i Srbije. ${ }^{14}$ Srbija je tijekom toga ekonomskog rata za izvoz i uvoz robe bila prinuđena koristiti samo solunsku osmansku prugu, koja je također bila pod kontrolom austrougarske prijestolnice. ${ }^{15}$ Zanimljivo je da se krajem 1906. javio sličan plan o balkanskoj transverzalnoj željeznici, čija je gradnja planirana od Ulcinja na Jadranu do Prahova na Dunavu, a trebala je ići preko Skadra, Prizrena, Peći, Mitrovice, Kuršumlije i Niša. Njezino financiranje i realizaciju trebao je preuzeti mješoviti francusko-talijansko-britanski konzorcij. Taj plan nije bio slučajan, jer su ga zagovarali upravo Talijani u okviru svoje balkanske politike, a i zbog suparništva s Austro-Ugarskom u ovom dijelu Europe. I premijer talijanske vlade Giovanni Giolitti i ministar vanjskih poslova Tomasso Tittoni toplo su preporučivali talijansko financijsko ulaganje u tu željeznicu. ${ }^{16}$

Austrougarski politički i vojni krugovi nisu krili svoje nezadovoljstvo tim srpskim i talijanskim namjerama, u kojima su bile uočljive ne samo ekonomske nego i političke pretenzije, jer bi takva transbalkanska željeznica u rukama Talijana ili Srba zasigurno ugrožavala vitalne interese Austro-Ugarske na ovom dijelu Balkanskoga poluotoka, tj. njezin strateški prodor do Soluna. Beču je također bilo jasno da Srbija pokušava ostvariti ne samo gospodarsko oslobađanje od Austro-Ugarske nego i teritorijalnu ekspanziju prema Albaniji,

12 KANN, A History of the Habsburg Empire, 464-466.

13 Tvorac toga željezničkog projekta Jovan Viclik pisao je 1896. Nikoli Pašiću: „Vrijeme je da Srbi dobiju željezni put do Jadrana i bratsku zajednicu Srbije s Crnom Gorom. [...] Tada će Srbija i Crna Gora imati slobodne ruke da se prošire u Bosni i Staroj Srbiji [Kosovo]” (ЂОРЂЕВИТ, „Пројект Јадранске железнице”, 4).

14 Austro-srpski gospodarski rat, poznat i kao „svinjski rat” (1906. - 1910.), koji je započeo austrougarskim bojkotom srpske žive stoke. Ta je borba potaknuta srpsko-bugarskim sporazumom pod utjecajem Rusije u travnju 1904. i srpsko-bugarskom carinskom konvencijom zaključenom 1905. godine.

15 РАТКОВИЋ, ЂУРИШИЋ, СКОКО, Србија и Црна Гора, 19.

16 ŠIŠIĆ, Predratna politika Italije, 56-57. 
koju su Austrijanci smatrali područjem vlastitoga utjecaja još od vremena Kultusprotektorata nad Albancima. ${ }^{17}$

Izgradnjom pruge koja bi povezala Dunav s Jadranskim morem Srbija bi u svojim rukama imala najvrednije balkanske arterije, postajući tako najvažnija tranzitna država na Balkanu. ${ }^{18}$ Od svih mogućih varijanti trgovačkoga izlaza na more srpska vlada izabrala je upravo onu rutu koja je vodila preko albanskih teritorija i završavala na albanskom primorju.

Prema srpskom željezničkom projektu iz 1906., pruga bi krenula od Dunava u Prahovo kod Negotina (s idejom da most i jedna grana pruge idu u Craiovou da bi se povezala s rumunjskim željezničkim sustavom), zatim bi nastavila Timočkom dolinom kod Zaječara i Kruševca, a odatle preko vododijelnice kroz tunel prema Nišu, gdje bi se susrela s postojećom glavnom linijom. Nastavljajući dalje preko Morave, pruga bi se spustila dolinom Toplice i nastavila u Prokuplje i Kuršumliju, gdje bi stigla do osmanske granice i vrha druge vododijelnice. U nastavku bi pruga išla kroz osmanski službeni teritorij, prolazila kroz Prištinu i Prizren, a zatim dolinom Drima do Skadra i Šenđina na albanskom primorju Jadranskoga mora. ${ }^{19}$

Iako je srpska vlada inzistirala na gospodarskom karakteru projekta, politička pozadina takva zahtjeva bila je očita. Tom željezničkom prugom Srbija je htjela postići tri cilja: prvo, dobiti izravnu vezu s morem, što bi nesumnjivo dalo prednost njezinu gospodarstvu; drugo, spriječiti prodor Austro-Ugarske na jug Balkana, što se također poklapalo s dugoročnim srpskim interesima; i treće, $s$ trgovačkim izlazom preko albanskoga primorja bilo bi lakše ostvariti nacionalni projekt Načertanije ${ }^{20}$, kao i grčko-srpski projekt iz 1861. o podjeli Albanije. ${ }^{21}$

U srpskoj historiografiji druge polovine XX. stoljeća nismo uočili neko znanstveno tumačenje pitanja zašto je Srbija nastojala da se njezina gospodarska neovisnost ostvaruje isključivo preko albanskih teritorija kada su joj bile dostupne lakše i jeftinije varijante, npr. preko Crne Gore. Srpski povjesničari

17 GOSTENTSCHNINGG, „Qёndrimet e Austro-Hungarisë ndaj Lëvizjes Kombëtare Shqiptare", 39-47.

18 Tom željeznicom koja bi prošla preko Kosova Srbija bi dobila izravan spoj s Crnom Gorom i Jadranskim morem s jedne te s Rumunjskom i Crnim morem, tj. Rusijom s druge strane (ŠIŠIĆ, Predratna politika Italije, 56).

19 BDOW-V-XXXIX, Extract from Annual Report for Servia for the Year 1906, VIII - Railways.

20 Prvi vanjskopolitički program Kneževine Srbije, koji je 1844. izradio ministar unutarnjih poslova Ilija Garašanin. Polazište programa bila je činjenica da je Srbija mala i da bi se trebala teritorijalno proširiti da bi postala moćna balkanska država, sposobna ostati neovisna o pretenzijama tadašnjih velikih sila. Dugoročni cilj projekta bilo je stvaranje velike srpske države koja bi uključivala Bosnu i Hercegovinu, „Staru Srbiju” (Kosovo), sjevernu Albaniju i nekoliko drugih pokrajina.

${ }^{21}$ Grčko-srpski tajni sporazum iz 1861., kojim je grčka strana tražila pripajanje Tesalije, Epira, Makedonije, Trakije i otočja Arhipelaga (Egejskoga mora), a Srbiji je dodijeljeno pravo pripajanja Bosne i Hercegovine, sjeverne Albanije (zajedno s Kosovom), čak i Crne Gore ako ova ne želi sačuvati svoju individualnost i neovisnost (ЈАКШИЋ, ВУЧКОВИЋ, Спољна политика Србије, 75). 
promatrali su taj željeznički program uglavnom kao „izraz velikog ekonomskog prosperiteta Srbije nakon preokreta iz 1903. godine". ${ }^{22} \mathrm{U}$ tom kontekstu navest ćemo neke informacije britanskih diplomata u vezi sa zahtjevima Crne Gore, koja je tražila da Srbija poništi plan izgradnje jadranske željeznice preko Albanije i nudila crnogorski projekt. U siječnju 1907. crnogorska vlada ponudila je Beogradu svoj projekt izgradnje željeznice, koja bi krenula od Bara, nastavila se uz Skadarsko jezero i dalje prema Novopazarskom sandžaku, gdje bi se povezala sa srpskim željeznicama. ${ }^{23}$ Crnogorska vlada nadala se da će Srbija prihvatiti njezin prijedlog i odbaciti jadranski željeznički projekt koji vodi do albanske luke, koja, po mišljenju crnogorske vlade, „nikada se ne bi mogla prilagoditi kao dio Velike Srbije". ${ }^{24}$ Prema crnogorskom planu, željeznička pruga od Srbije do Bara, kao transbalkanska željeznica, bila bi kraća i prolazila bi preko osmanskoga teritorija u dužini od samo $100 \mathrm{~km}$, a dunavsko-jadranska željeznička pruga do Albanije koju je predložila Srbija „bila bi još duža i još teža za izgradnju zbog neprijateljske populacije". ${ }^{25} \mathrm{Da}$ bi osigurala financijsku i političku potporu tom projektu, crnogorska je vlada intenzivno lobirala u sjedištima velikih sila, posebno u Londonu, Parizu i Rimu. ${ }^{26}$ Računala je na to da bi britanske i francuske tvrtke lakše mogle dobiti koncesiju od Porte za izgradnju te pruge. Britanska vlada primila je crnogorsku ideju s izvjesnom zadrškom, strahujući da bi loše financijsko stanje crnogorske vlade i siromaštvo pokrajina kroz koje bi pruga prolazila mogli donijeti gubitke britanskim građevinskim tvrtkama. Međutim, Crnogorci su obećali da će od Bara napraviti slobodnu luku da bi tvrtka koja bi se angažirala na izgradnji željeznice dobila naknadu u vidu zemljišnih potpora koje bi joj mogle donijeti korist. ${ }^{27}$ Unatoč inzistiranju Crne Gore na projektu Bar - Novi Pazar - Srbija, srpska vlada nije odustala od svojega projekta preko Kosova do albanske luke Šenđin. Usprkos negativnom odgovoru Beograda, crnogorska vlada i njezin knez nisu se pokolebali, nego su nastavili tražiti diplomatsku i financijsku potporu za svoj projekt. ${ }^{28} \mathbf{U}$ međuvremenu su Crnogorci obaviješteni iz neslužbenih izvora o austrijskom pokušaju dobivanja koncesije od Porte za izgradnju željezničke pruge Mitrovica - Skadar - Šenđin, a u slučaju odbijanja samo Skadar - Šenđin. Crnogorska je vlada također doznala da se francusko-talijanski sindikat bavi željezničkom koncesijom u Istanbulu u okviru srpskoga projekta (Niš - Priština - Prizren Šenđin). Ta nova priopćenja uvelike su uznemirila crnogorsku vladu jer ako bi se ostvarila samo jedna od tih željeznica, Crna Gora mogla je ostati odsječena od komunikacije s ostatkom Balkana..$^{29}$ Andrija Radović, bivši ministar finan-

\footnotetext{
22 MARIĆ, STOŠIĆ, Srbija 1914, 11.

23 BDOW-V-XXXIX, No. 221, Mr. Whitehead to Sir Edward Grey, Belgrade, January 7, 1907.

24 Isto.

25 Isto.

26 BDOW-V-XXXIX, No. 221, 222, 223, 226.

27 BDOW-V-XXXIX, No. 221.

28 Isto.

29 BDOW-V-XXXIX, No. 222, Report by Italian Minister at Cettinjé on the contemplated Railway from Antivari to Niš, Cettinjé, January 23, 1907.
} 
cija crnogorske vlade, preuzeo je 23. siječnja 1907. dužnost od kneza Nikole da se obrati talijanskom veleposlaniku u Cetinju kako bi izrazio zabrinutost crnogorske vlade. Da pridobije i zainteresira Italiju, Veliku Britaniju, Francusku i Rusiju za crnogorski, a ne srpski projekt, crnogorska je vlada detaljno obrazložila svoj projekt, ističući prednosti Bara u odnosu na Šenđin, posebno geopolitičku prednost, a ponudila je i razne ekonomske beneficije za zainteresirane sile. Suština crnogorskoga lobiranja sastojala se od sljedećih točaka:

- Željeznica će polaziti iz Bara, proći kroz Podgoricu, Nikšić i Andrijevicu, a zatim kroz Berane, Rožaje i Mitrovicu na turskom teritoriju. Stići će do srpske granice kod Kuršumlije, a zatim nastaviti do Niša, na udaljenosti od oko 400 kilometara, što će stajati oko 120 milijuna franaka.

- Niš će, prema planu srpske vlade, biti izravno povezan s rumunjskim željeznicama, a zatim s Crnim morem.

- Beskrajne i bogate pokrajine Donje Rusije, Rumunjske, Bugarske i Srbije dobit će izravnu vezu sa Zapadom i Jadranom.

- Ta će linija djelomično uravnotežiti utjecaj željezničkoga monopola Centralnih sila, čineći ga vrlo pogodnim za francusku, britansku, belgijsku i švicarsku trgovinu s Istokom.

- Ta će linija biti osobito u interesu talijanske trgovine, favorizirajući položaj Venecije, grada predodređenog da postane prva europska luka, ne računajući ovdje ostale vrlo očite prednosti koje bi dobila industrija doline rijeke Po i talijanske obale Jadrana od izvoza poljoprivrednih proizvoda.

- Luka Bar bit će u rukama talijanskoga koncerna.

- Za razliku od Bara, luka Šenđin zahtijeva kontinuirano čišćenje mulja koji nanose Bojana i Drim.

- Bar je u odnosu na Šenđin zdravija pokrajina.

- Bar nudi dovoljno područja potrebnih za skladištenje robe, ispašu stoke tijekom prijevoza i sl., a uočljiv je nedostatak tih uvjeta u pustoj regiji Šenđina.

- Da bi se olakšala trgovina, Bar će u idućih petnaest godina biti proglašen slobodnim gradom. ${ }^{30}$

Ono što je Cetinje neposredno željelo zapravo je bilo koordinirano angažiranje velikih sila u Istanbulu, posebice Velike Britanije i Italije, te financijska potpora za taj projekt. ${ }^{31}$ Štoviše, knez Nikola priopćio je otpravniku poslova u britanskom veleposlanstvu u Cetinju Charlesu des Grazu da „ako željeznica ne prođe kroz kneževinu [Crnu Goru], s izlazom u luku Bar, to bi bila politička i ekonomska smrt za Crnu Goru" ${ }^{32}$ Samo pomoću te željeznice, prema riječima crnogorskoga kneza, „mogao bi se postići razvitak zemlje i zapošljavanje stanovništva u njihovoj domovini, a ne emigracija u Ameriku u potrazi

\footnotetext{
30 Isto.

31 Isto.

32 BDOW-V-XXXIX, No. 223, Mr. des Graz to Sir Edward Grey, Cettinjé, March 4, 1907.
} 
za poslom" ${ }^{33}$ Knez Nikola zamolio je britanskoga diplomata da uz svoje zalaganje vjerno prenese njegov zahtjev u Londonu. Isto je učinio i s diplomatima Francuske, Italije i Rusije, a uvijek je vodio računa da za crnogorski projekt ne dozna Austrija. ${ }^{34}$ Međutim, oklijevanje britanske vlade, dvora i Odbora za trgovinu nije bilo samo političke nego i ekonomske prirode. Britanski trgovinski odbor bio je odlučan u svojoj procjeni da transbalkanski projekt Crne Gore nosi u sebi mnogo nedostataka i ne pruža neku veću i sigurnu korist za britansku trgovinu, stoga nije mogao biti prihvaćen. ${ }^{35}$

\section{Diskurs o transbalkanskim željeznicama}

Srbija je ostala čvrsta u stavu da će njezina jadranska željeznica ići u Šenđin, a ne u Bar. Drugim riječima, iza ekonomskoga bili su skriveni politički i ekspanzionistički ciljevi. Od travnja 1907. srpska vlada intenzivirala je diplomatsku propagandu, tražeći financijsku potporu u Londonu, Parizu, Rimu i Sankt Peterburgu. Velika Britanija, iako je općenito podržavala razvitak prometa u tom dijelu Europe, u pitanju srpskoga željezničkog projekta držala se suzdržano. Pozivajući se na pretpostavku o spajanju Srbije s Crnom Gorom i primorjem preko Kosova, kralj i britanska vlada bili su svjesni mogućega austrijsko-njemačkog protivljenja, pa su zato mislili da bi „austrijsko protivljenje moglo biti slabije ako se [od Srbije] traži da ruta [željeznice] ide preko Novopazarskoga sandžaka" ${ }^{36}$, a ne preko Kosova. I vlade Italije i Francuske, unatoč spremnosti da pomognu Srbiji u realizaciji njezina željezničkoga projekta, bile su svjesne poteškoća u dobivanju koncesije od Porte. ${ }^{37}$ Jasno je bilo svima, pa i Austro-Ugarskoj, da Porta, odnosno sultan, „neće nikad dopustiti da se plan izvede zbog zategnutih odnosa sa Srbijom, te zbog ustaša u Maćedoniji i Albaniji" ${ }^{38}$

Prema hrvatskoj znanstvenici Šarloti Đuranović, iza srpskoga projekta bila je ruska vlada, koja je „uz saglasnost Srbije htjela povezati Rusiju preko Rumunije i Srbije s Jadranskim morem". ${ }^{39}$ Iako se ta konstatacija podudara sa suštinom programa ruskoga panslavizma, moramo ovom prilikom spomenuti da diplomatski dokumenti zapadne provenijencije sugeriraju da je ruska vlada tijekom toga razdoblja bila jako oprezna i nije se službeno oglasila o srpskom projektu. Dakle, Rusija nije htjela izazvati Austro-Ugarsku iako je taj projekt išao u prilog njezinim dugoročnim težnjama na ovom dijelu Balkana. Štoviše,

\footnotetext{
33 Isto.

34 Isto.

35 BDOW-V-XXXIX, No. 226, Board of Trade to Foreign Office. Board of Trade, May 24, 1907.

36 BDOW-V-XXXIX, No. 224, Sir Edward Grey to Mr. Whitehead, Foreign Office, April 8, 1907; Doc. No. 223, Mr. des Graz to Sir Edward Grey, Cettinjé, March 4, 1907.

37 Isto.

38 ŠIŠIĆ, Predratna politika Italije, 57.

39 ĐURANOVIĆ, Opća povijest, 152.
} 
ruski ministar vanjskih poslova Aleksandar Izvoljski imao je izvjesne zadrške i u vezi s fizičkim i financijskim poteškoćama u realizaciji željezničkih projekata Srbije i Crne Gore. ${ }^{40}$

Upravo u takvim okolnostima austrougarska vlada, koja se osjećala isprovociranom od Srbije i Italije, krajem 1906. dobiva potporu Berlina za ponovno aktualiziranje sandžačke željeznice. ${ }^{41}$ Istodobno se Dunavska Monarhija povezala s Bugarskom kao svojom prirodnom saveznicom te su zajednički poduzele snažne diplomatske akcije pri Porti i velikim silama da bi spriječile financiranje srpskoga projekta. U siječnju 1907. ministar vanjskih poslova Austro-Ugarske Aloys Lexa von Aehrenthal obavlja pripreme za diplomatsku akciju oko sandžačke željeznice. Početkom svibnja 1907. Aehrenthal ponovo traži diplomatsku potporu Berlina, koja mu bez rezervi biva obećana. Potom 27. prosinca 1907. austrougarski veleposlanik u Istanbulu Giovanni Marchese Pallavicini traži od sultana Abdula Hamida koncesiju za izgradnju željeznice Uvac - Mitrovica, s motivacijom da će ta pruga „još više razdružiti oba turska neprijatelja, Srbiju i Crnu Goru". ${ }^{2}$ Za taj projekt Beč je tražio koncesiju i mogućnost da odmah započne opservaciju. ${ }^{43}$ Dakle, Austro-Ugarska se željeznicom od Uvca preko Novopazarskoga sandžaka do Mitrovice na Kosovu, kao nastavkom bosanske željeznice, trebala povezati s Istočnom željeznicom. ${ }^{44}$

Britanska diplomacija bila je uvjerena da bi sultan mogao dati koncesiju austrougarskoj vladi samo kao protuuslugu za zalaganje Beča kod drugih velikih sila da smanje pritisak na Istanbul vezano za provedbu reformi u Makedoniji. ${ }^{45}$ Te su vijesti kružile u Parizu i Sankt Peterburgu iako su ih Beč i Berlin u više navrata opovrgnuli. No kada je krajem siječnja 1908. Porta i formalno odobrila koncesiju (irada) Austro-Ugarskoj, a ministar Aehrenthal tu informaciju javno objavio 27. istog mjeseca, nastaje međunarodna kriza zbog austrijsko-ruskih odnosa. Reakcije u Rusiji, posebno u ruskim novinama Novoe Vremja, Slovo i Rus, bile su žestoke. Iako su ti listovi imali različita politička

40 BDOW-V-XXXIX, No. 225, Sir A. Nicolson to Sir Edward Grey, St. Petersburgh, April 22, 1907; ПЕРОВИЋ, Први балкански рат, 45-46.

${ }_{41}$ ŠIŠIĆ, Predratna politika Italije, 56.

42 Isto, 57.

43 BDOW-V-XXXIX, No. 227, Sir A. Nicolson to Sir Edward Grey, St. Petersburgh, January 30, 1908; TNA-PRO-FO, BD 1898-1914, Vol. V, 01968, Railways, 284. - Prema riječima N. Richa, „cilj Austro-Ugarske bio je pojačati kontrolu nad Sandžakom, koji bi trebao poslužiti kao klin između Srbije i Crne Gore da bi se zaustavilo političko jedinstvo tih dvaju etnički povezanih naroda i sačuvao njezin prolaz na području osmanske Makedonije i odavde do Egeja, odnosno u Solunu”. U međuvremenu su Srbi komentirali austrijski željeznički projekt kao „pokušaj jačanja austrijske kontrole nad Sandžakom i proširenja austrijskoga političkog i gospodarskog utjecaja na cijelom južnom Balkanu” (RICH, Diplomacia e Fuqive të Mëdha, 409-410).

${ }_{44}$ Osmansko Carstvo izgradilo je željezničku prugu Solun - Mitrovica 1873. godine. Radove je obavila austrijska tvrtka (na temelju sporazuma iz 1869.) od turske granice do Uvca, a druga grana, istočna, išla je od srpske granice do Vardišta. Novi prijedlog zahtijevao je nastavak puta od Uvca do Mitrovice, terminala koji je krenuo iz Soluna (BDOW-V-XXXIX, Doc. No. 230, Sir. E. Goschen to Sir Edward Grey, Vienna, February 5, 1908, Enclosure in No. 230. Memorandum by Mr. Gregory on Baron von Aehrenthal's „Exposé”).

45 Isto. 
stajališta, jednoglasno su bili protiv obraćanja austrijskoga ministra vanjskih poslova Aehrenthala u austrougarskom parlamentu. Ruski tisak ocijenio je Aehrenthalov govor kao subverziju austrijsko-ruskoga sporazuma sklopljena u Mürzstegu 8. kolovoza 1903. o reformama u Makedoniji, zanemarujući tako interese balkanskih naroda. List Novoe Vremja među ostalim je naglasio:

„Austro-Ugarska je predložila izgradnju pruge koja povezuje postojeće željeznice s Balkanskim poluotokom, koja će povezivati Berlin izravno s Atenom i Pirejom te dalje do Egipta i Indije. Ovaj plan usmjeren je na finalizaciju germanizacije Bliskoga istoka, a cijeli projekt nije ništa drugo doli razvoj velikoga projekta istočnonjemačke željeznice u pravcu Sredozemlja, koji će dati prednosti samo Njemačkoj i Austro-Ugarskoj, ugrožavajući sve ostale. Barun Aehrenthal nesumnjivo živi na Mjesecu i zaboravlja da uz Turke i Grke na Balkanu postoje i milijuni Slavena." ${ }^{46}$

\section{Umjereni liberalni list Slovo uz ostalo kaže:}

„Vidjet ćemo Makedoniju presječenu austrijskom željeznicom od Mitrovice do Skopja, a kako se turska linija povezuje s grčkim željeznicama via Larisa, Beč će biti u izravnoj vezi s Pirejom. Nije teško shvatiti kakav će učinak taj sporazum imati među slavenskim narodima na Balkanu. Ako postoji nešto što može potaknuti izbijanje daljnjih neprijateljstava, onda je to taj sporazum. Balkanski Slaveni dugo su vremena u prošlosti, i to ne bez razloga, sumnjali u Austrijance: oni mrze Grke na Balkanu ništa manje nego Turke, a dogovor među ta tri elementa lako može postati iskra koja će zapaliti cijeli Balkan. Ako se to naziva pacifikacijom, onda je nedvojbeno riječ o tipično austrijskoj metodi." ${ }^{77}$

\section{Drugi ruski liberalni list, Rus, pisao je:}

„Barun Aehrenthal pronašao je fascinantan način da obavijesti Rusiju kako je dogovor o Balkanu dovršen. Izgradnja željezničke pruge koristit će samo $\mathrm{Au}$ stro-Ugarskoj i bit će od velike koristi i u političkom i u gospodarskom pogledu. Aehrenthalova izjava o željezničkom projektu očito daje na znanje da se pregovori s Turskom o ovom pitanju uspješno razvijaju. Ako je tako, onda Rusija treba imati na umu činjenicu da su joj vrata otvorena i da bi prvi zadatak njezine diplomacije trebao biti jednostrana akcija s Turskom u smislu suprotstavljanja austrijskim željama." ${ }^{48}$

Diplomatska prepiska tijekom toga razdoblja potvrđuje nam da je ruski dnevni tisak vezano uz balkanske željeznice imao određeni utjecaj ne samo na javno mišljenje nego i na rusku vladu. Budući da se sporazum u Mürzstegu smatrao poništenim, to će i Rusiji i Austro-Ugarskoj dati slobodne ruke u njihovoj balkanskoj politici. Britanski veleposlanici javljaju tih dana da je pitanje austrijske sandžačke željeznice izazvalo ogorčenje i nepovjerenje u Sankt Pe-

\footnotetext{
46 Isto.

47 Isto.

48 Isto.
} 
terburgu i ljubomoru u Rimu. ${ }^{49}$ No vijesti o koncesiji za austrijsku sandžačku željeznicu nisu primljene s nezadovoljstvom samo u Rusiji i Italiji nego i u Srbiji i Francuskoj. ${ }^{50}$ Čak je i britanska vlada reagirala na tijek događanja. Britanski ministar vanjskih poslova Sir Edward Grey izjavio je austrijskom veleposlaniku u Londonu da „koincidiranje pregovora o reformama u Makedoniji sa sultanovom iradom u korist austrijskih željezničkih projekata upućuje na to da, dok se mi zadužujemo u Istanbulu s odgovornošću za inicijativu prijedloga reformi u Makedoniji, druge pak sile [aludirajući na Austro-Ugarsku i Njemačku] dobivaju koncesije od sultana i opstruiraju reformu" ${ }^{51}$ Iznenađen izjavama britanskoga ministra, Beč je u više navrata pokušavao uvjeriti europske sile da nema nikakve veze između Mürsztega i željezničkoga programa. Austrijski željeznički projekt, prema Ballhausplatzu ${ }^{52}$, ticao se isključivo domene ekonomsko-trgovinskih interesa, koji nisu mogli čekati svršetak reformi u Makedoniji jer bi to značilo nekoliko godina čekanja. ${ }^{53}$

Najava da će austrijska sandžačka željeznica imati važnu postaju u Mitrovici te da će proći kroz većinu područja Kosovskoga vilajeta naseljenih pretežno Albancima izazvala je znatnu zabrinutost među albanskim stanovništvom. Albanci su gledali na sandžačku prugu u uskoj vezi s austrijsko-ruskim reformama za Makedoniju, koje su izravno prijetile da će dovesti do rascjepa albanskih teritorija. Zato je tijekom 1908. nepovjerenje albanskoga stanovništva na Kosovu prema svakoj austrijskoj, ruskoj i srpskoj akciji bilo uočljivo i permanentno. Na to navodi i izvještaj britanskoga vicekonzula u Skopju H. E. Satowa od 11. srpnja 1908. godine:

„Čast mi je izvijestiti da je posljednjih nekoliko dana došlo do znatnoga uzbuđenja među Albancima u okrugu Ferizovića (Uroševac). Čini se da je osnovni razlog toga uznemirenja jednostavan, tj. organiziranje izletničkoga vlaka za potrebe austrijsko-njemačke (željezničke) škole u selo Saratište u blizini Ferizovića, koji je bio planiran za nedjelju 5. srpnja. Za taj događaj pripreme su obavljene u šumi u blizini sela, gdje je podignuta plesna platforma, a i dekoracija je postavljena, uključujući i nekoliko austrijskih zastava. Čini se da se vijest o predstojećem upadu Austrijanaca i njihovih obitelji brzo proširila na širokom području, a Albanci su se počeli okupljati, što je rezultiralo otkazivanjem ideje o izletničkom vlaku. U nedjelju, prema vozaču koji je prevezao vlak u Mitrovicu, linija između stanica Kačanik i Lipljan pažljivo je praćena od

\footnotetext{
49 BDOW-V-XXXIX, No. 229, Sir N. O’Conor to Sir Edward Grey, Pera, February 5, 1908.

50 ЂОРЂЕВИЋ, „Пројект Јадранске железнице”, 10.

51 BDOW-V-XXXIX, No. 231, Sir Edward Grey to Sir A. Nicolson, Foreign Office, February 10, 1908.

52 Ministarstvo vanjskih poslova Austro-Ugarske do 1918. godine.

53 BDOW-V-XXXIX, No. 235 (a), Extract from Speech by Baron von Aehrenthal respecting the Triple Alliance, Macedonian Affairs, and Projected Sanjak Railway; No. 235 (b), Précis by Mr. Gregory of an Article in the „Neue Freie Presse” commenting on Baron von Aehrenthal's Speech of February 14, 1908; No. 236, Sir E. Goschen to Sir Edward Grey, Vienna, February 15, 1908.
} 
strane Albanaca koji su bili spremni otjerati uljeze, dok je plesna platforma u šumi bila spaljena." ${ }^{4}$

U Sankt Peterburgu je austrijska sandžačka pruga kvalificirana kao poražavajući čimbenik austrijsko-ruskih balkanskih sporazuma iz 1897. i 1903., pa je sada ruska diplomacija počela otvoreno podržavati zahtjev Srbije za izgradnju jadranske željeznice. ${ }^{55}$ Prvi korak ruske vlade bilo je angažiranje ruske diplomacije u Istanbulu na dobivanju koncesije za željeznicu u okviru srpskoga projekta. ${ }^{56}$ Rusko lobiranje za srpski projekt nastavilo se i preko veleposlanstava drugih sila, posebno britanskoga veleposlanstva u Sankt Peterburgu. ${ }^{57}$ Vjerojatno je dio toga lobiranja i aktivnosti bilo i angažiranje francuskoga znanstvenika ruskoga podrijetla Aleksandra Aleksandroviča Bašmakova (1858. 1943.), poznatog po putopisu A Travers le Monténégro et le pays des Guègues (Kroz Crnu Goru i zemlju Gega), objavljenom u Sankt Peterburgu 1911. godine. Bio je to opis posjećenih područja Crne Gore, sjeverne Albanije i Kosova od rujna do listopada 1908. s misijom promatranja regije kuda bi navodno trebala proći jadranska pruga prema srpskom željezničkom projektu. ${ }^{58}$

Velika Britanija, koja je imala izvjesne političke koristi od austrijsko-ruskih nesuglasica, počela je sada raditi na jačanju svojega položaja u balkanskim pitanjima da bi postupno zamijenila Austriju kao glavnoga ruskog partnera, ali i da bi prevladala rusko natjecanje u Aziji. Prema britanskoj diplomaciji, „djelovanje Austrije učinit će da se Rusija u budućnosti sve više oslanja na nas" ${ }^{59}$ No ruska diplomacija pronašla je još ozbiljniju potporu kod francuskih financijera, koji su bili zainteresirani za poticanje Srbije k austrijskoj ruti prodora da bi blokirali njemački Drang nach Osten prema Istanbulu i Solunu. ${ }^{60}$

Stajalište Njemačke u diskursu o transbalkanskim željeznicama bilo je vrlo važno, ne samo za Austro-Ugarsku nego i za druge sile. Njemačka je smatrala da je pravo na strani Austrije i da njezin zahtjev ima istinsku potporu u Berlinskom ugovoru iz 1878. godine. Njemačka vlada bila je stajališta da se radi o projektu ekonomskoga karaktera koji je u duhu austrijsko-ruskoga sporazuma i programa iz Mürzstega te da Austrija ne zahtijeva izgradnju željeznica nauštrb reformi. ${ }^{61}$ Njemačka se vlada izjasnila da ona nije pokrenula prijedlog toga

54 BM-BL-AAP (56) 1909. CV. 105. Turkey. No. 1 (1909) Correspondence respecting the Constitutional Movement in Turkey, 1908. Inclosure in No. 6. Vice-Consul Satow to ConsulGeneral Lamb, Uskub, July 11, 1908.

55 ЂОРЂЕВИЋ, „Пројект Јадранске железнице”, 10.

56 BDOW-V-XXXIX, No. 236, Sir E. Goschen to Sir Edward Grey, Vienna, February 15, 1908.

57 TNA-PRO-FO, BD 1898-1914, Vol. V, 01968, Railways, p. 284.

58 „[... Put ga je odveo od Cetinja u Tuz, u dolinu rijeke Cijevne (Gruda i Keljmend) u Gusinje i Plav i preko Rugove na Kosovo, gdje je posjetio Peć, Dečane, Đakovicu i Prizren. Iz Prizrena se vratio na obalu kroz Kukës, Puku, Vau i Dejes i Šenđin. [...] Iako plan o željezničkoj pruzi nije ostvaren, s toga su putovanja ostale brojne fotografije. Poslije je Bašmakov bio profesor na Antropološkoj školi u Parizu [...]” (ELSIE, Early photography in Albania).

59 RICH, Diplomacia e Fuqive të Mëdha, 410.

60 MICHON, The Franco-Russian Alliance, 233.

${ }_{61}$ BDOW-V-XXXIX, No. 238, Sir Edward Grey to Sir F. Lascelles, Foreign Office, February 24, 1908. 
projekta u Beču, iako je iskreno podržavala njegovu realizaciju jer bi izgradnja te pruge pozitivno utjecala na gospodarske i moralne uvjete gdje god bi željeznica prošla, što bi utjecalo i na pacifikaciju tih zemalja. Zato je Berlin bio spreman podržati austrijski projekt u Istanbulu, no ne samo taj nego i slične projekte drugih država. ${ }^{62}$

Bugarska se nije protivila sandžačkoj željeznici. Štoviše, upravo je srpski željeznički projekt smatrala vrlo štetnim za bugarske interese jer bi preusmjerio rumunjski trgovinski promet na srpski teritorij, čime bi se izjalovila dugo gajena nada o povezivanju bugarskoga željezničkog sustava s rumunjskim preko Svištovskoga mosta, što bi Bugarskoj omogućilo povezivanje s Europom zaobilazeći Srbiju ${ }^{63}$ Bugarski je tisak procijenio da je jedino rješenje protiv izolacije Bugarske inzistiranje na izgradnji željezničke pruge Ćustendil - Kumanovo, koja bi Sofiju dovela u izravnu vezu sa Skopjem i Solunom, a poslije i Jadranom. Uskoro je bugarska vlada osmislila svoj konkretni projekt za izgradnju željezničke pruge Ćustendil - Kumanovo - Skopje - Gostivar - Debar - Šenđin. ${ }^{64}$ Ta bi željeznica, ako bi se ostvarila, bila od velike gospodarske, političke i strateške važnosti za Bugarsku jer bi se dio njezina izvoza otpremao u zapadnu Europu preko solunske luke. Također bi se na makedonskom tržištu plasirali bugarski proizvodi, što bi dodatno ojačalo politički utjecaj Bugarske u Makedoniji. ${ }^{65}$ No, srpska se vlada ubrzo angažirala u Istanbulu ne bi li opstruirala bugarski projekt. ${ }^{66}$

62 Isto.

63 BDOW-V-XXXIX, Doc. No. 237, Mr. C. Berclay to Sir Edward Grey, Sophia, February 19, 1908. - „Bugarsko-rumunjski sporazum doimao se sasvim blizu dogovora jer most između Srbije i Rumunjske još nije bio izgrađen, ali pregovori nisu uspjeli zbog tvrdoglavosti obiju strana. Bugarska nije htjela premjestiti točku veze iz grada Roussea ili Svištova dalje od Borila, a Rumunjska je inzistirala na vezi Corabia - Gigen. Kada su se bugarski inženjeri konačno složili s projektom, usprkos poteškoćama u močvarnoj dolini Karaboaza, Rumunji su odjednom odgodili rad mješovitih komisija još jednom promijenivši mjesto mosta: na Becket - Oriahovo, u nadi da će tako bolje 'štititi' Constanţu od konkurencije Varne" (DZHALEVA-CHOKOVA, „Balkans Railways Development”).

${ }^{64}$ ПЕРОВИЋ, Први балкански рат, 45.

${ }_{65}$ СКОКО, Други балкански рат, 57.

${ }_{6}$ РАТКОВИЋ, ЂУРИШИЋ, СКОКО, Србија и Црна Гора, 19. 


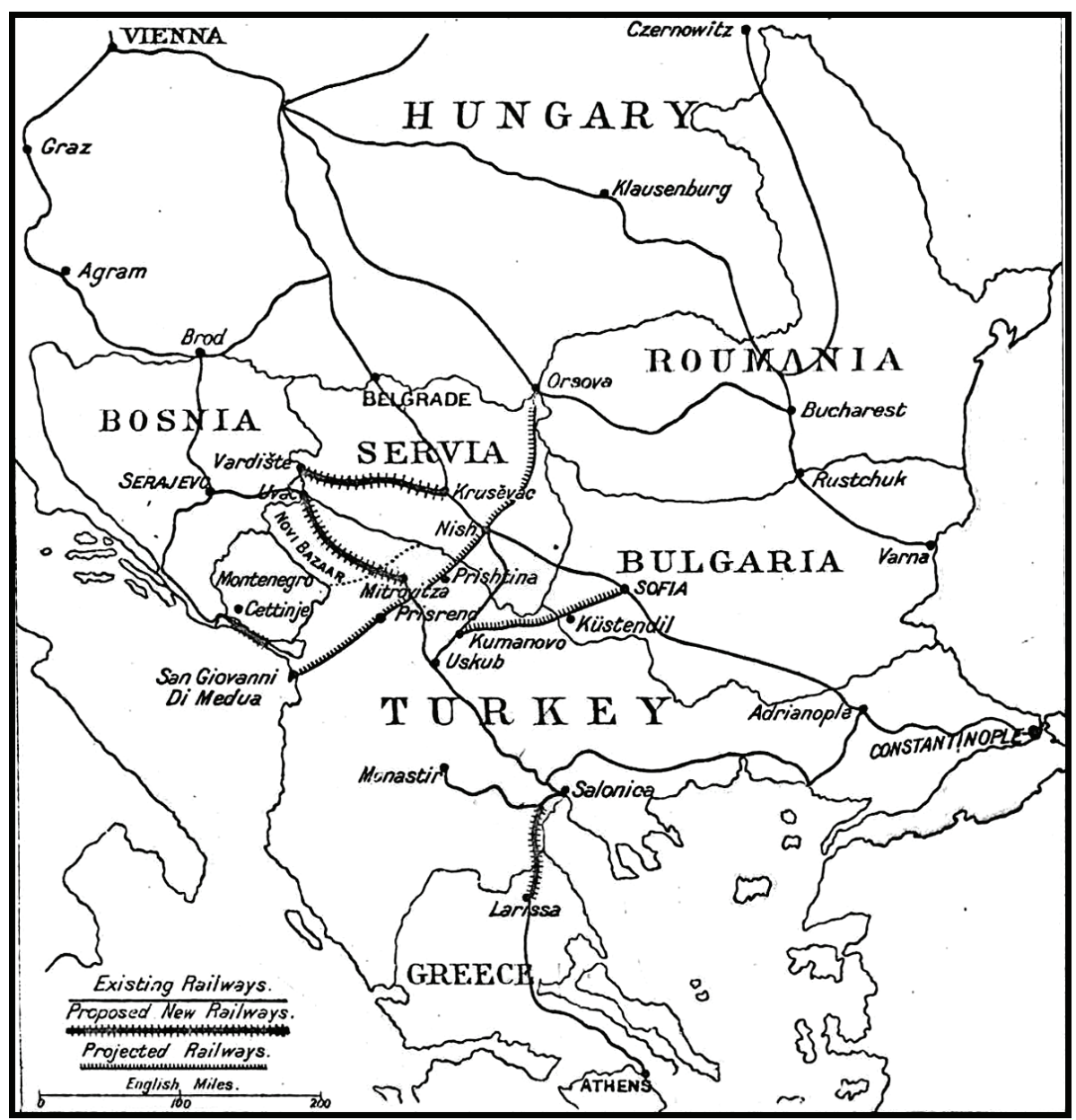

Mreža balkanskih željeznica u prvom desetljeću XX. stoljeća: postojeće željeznice, predložene željeznice i projekti željeznica ${ }^{67}$

Italija se također oglasila sa svojim željezničkim projektom, koji bi krenuo iz Vlore ili Drača prema Bitolju do Soluna, trasom drevne ceste Via Egnatia iz vremena rimskoga prodora na Balkan. ${ }^{68}$ Željeznicu su planirali izgraditi Schneider i Vitali uz pomoć Banque Ottomane i Banque de Paris et des Pays-Bas. ${ }^{69} \mathrm{I}$ Grčka je izišla s projektom željezničke pruge Larisa - Solun. Grčka je svoj zahtjev za koncesiju pravdala ističući da je jedina balkanska država koja nema željezničke veze s drugim državama. Europskim silama i Porti jamčila je da njezin projekt željeznice nema ni politički ni strateški nego isključivo ekonomski cilj. ${ }^{70}$

\footnotetext{
67 TNA-PRO-FO, BDOW, Vol. V, 01969.

68 MARIĆ, STOŠIĆ, Srbija 1914, 11.

69 MICHON, The Franco-Russian Alliance, 233.

70 BDOW-V-XXXIX, No. 252, Mr. G. Barclay to Sir Edward Grey, Pera, April 28, 1908.
} 
Austrijsko-srpsko suparništvo i nepovjerenje u pitanju željezničkih projekata dodatno je pojačano kada je Beč predložio Beogradu trgovački izlaz Srbije na Jadransko more preko svoje bosanske željeznice, linijom Višegrad - Sarajevo - Metković. ${ }^{71}$ Srpska vlada kategorički odbacuje taj prijedlog, baš kao što je nedugo prije toga odbila crnogorski prijedlog o izlasku njezine željeznice u Bar umjesto u Šenđin. ${ }^{72}$

U ožujku 1908., nakon dobivanja financijske potpore u vidu francuskoga, britanskoga, ruskoga i talijanskoga kapitala, srpska vlada zatražila je od Porte koncesiju za izgradnju svoje jadranske željeznice. ${ }^{73}$ Iako se nije službeno oglasila protiv dodjele koncesije, Porta je na razne načine prolongirala davanje konačna odgovora. U tim se okolnostima balkanske države zainteresirane u pitanju željezničkih projekata gotovo istodobno obraćaju Foreign Officeu za potporu u Istanbulu. Međutim, Greyov odgovor bio je jednak za sve: „Ne možemo podržati željezničke projekte u Istanbulu budući da smatramo neprikladnim gurati naprijed zahtjeve za koncesije balkanskih željeznica u ovom osjetljivom trenutku kada su pregovori o reformama u Makedoniji na kritičnoj točki." ${ }^{4}$ Dakle, prema britanskoj diplomaciji, izabran je pogrešan trenutak za takve zahtjeve, te zato Foreign Office ni na koji način nije prihvatio vršiti pritisak na Portu bez obzira na to o kojem se projektu radilo. ${ }^{75}$

Koliko je pitanje balkanskih željeznica dobilo politički karakter vidi se i po tome što je sastanak britanskoga kralja Edwarda s ruskim carem Nikolom, koji je u lipnju 1908. održan u baltičkoj luci Reval (dan. Tallinn) u Estoniji, ostvaren upravo po sugestiji britanske diplomacije da Rusiju potpuno odvoji od Njemačke, uzevši kao povod neraspoloženje u Rusiji zbog Aehrenthalove sandžačke željeznice. ${ }^{76}$ Diskurs o balkanskim željezničkim projektima nastavio se i tijekom ljetnih mjeseci 1908. godine. Velike sile Trojne antante, zajedno s Italijom, počele su vršiti latentan pritisak na Portu, uvjetujući dodjelu koncesije za austrijski željeznički projekt istodobnom dodjelom koncesije i za srpski željeznički projekt. ${ }^{77}$ No Porta nastavlja prolongirati konačnu odluku o dodjeli koncesija bez obzira na to o kojem se projektu radilo. Stav Porte u vezi s dodjelom koncesija najbolje ilustrira sastanak britanskoga diplomata G. Lowthera s velikim vezirom, kada potonji izražava svoje osobno, a i uvjerenje Porte i sul-

\footnotetext{
${ }_{71}$ ПЕРОВИЋ, Први балкански рат, 46-47.

72 ЂОРЂЕВИЋ, „Пројект Јадранске железнице”, 47.

73 Kapital koji bi financirao izgradnju te pruge bio bi $40 \%$ iz Francuske i po $15 \%$ iz Velike Britanije, Rusije, Italije i Srbije. Francuska vlada inzistirala je na tome da nema nikakvu inicijativu u balkanskim pitanjima i htjela je djelovati samo zajedno s drugim silama (BDOW-VXXXIX, No. 243, Sir F. Bertie to Sir Edward Grey, Paris, March 3, 1908).

74 BDOW-V-XXXIX, No. 240, Sir Edward Grey to Mr. Whitehead, Foreign Office, February 25, 1908; No. 249, Memorandum communicated to M. Métaxas, March 17, 1908.

75 BDOW-V-XXXIX, No. 244, Memorandum communicated to Count Benckendorff, March 4, 1908.

76 ŠIŠIĆ, Predratna politika Italije, 57-58.

77 BDOW-V-XXXIX, No. 251, Sir Edward Grey to Count de Bostardi, Foreign Office, April 16, 1908; No. 254, Sir Edward Grey to Count Benckendorff, Foreign Office, July 15, 1908.
} 
tana, da željeznički projekti Srbije, Austro-Ugarske, Bugarske, Grčke i drugih „imaju čisti politički i strateški karakter”. ${ }^{78}$

Pitanje željezničkih projekata u susretu s velikim političkim događajima

Godine 1908. - 1912. donijele su velike promjene na političkoj sceni Balkana, što je imalo znatan utjecaj i na balkanske željezničke projekte. Rusija i Austro-Ugarska, iako su se javno natjecale u mnogim političkim i geostrateškim pitanjima, pa tako i željezničkim projektima, istodobno su održavale i tajne sastanke i dogovore. Budući da je uspjeh Mladoturske revolucije iz srpnja 1908. mogao oslabiti položaj Beča i Sankt Peterburga u Istanbulu, 15. rujna 1908. ministri vanjskih poslova Austro-Ugarske i Rusije Aehrenthal i Izvoljski potpisuju u Buchlauu sporazum prema kojem je Rusija načelno prihvatila plan Austro-Ugarske za aneksiju Bosne i Hercegovine, a austrougarski ministar obećao je pomoći Rusiji da njezina ratna flota dobije slobodan prolaz kroz tjesnace Bospor i Dardaneli. Tako je u idućim mjesecima pitanje željeznica palo u drugi plan kao posljedica događaja i kriza koje su zahvatile Balkan tijekom iste godine, posebice aneksijske krize oko Bosne i Hercegovine, proglašenja neovisnosti Bugarske i grčkoga proglašenja aneksije Krete.

Iako su ti događaji donijeli veliku uznemirenost i konfuziju, srpska vlada nije prekidala pokušaje realizacije svoje željeznice. Ubrzo nakon svršetka aneksijske krize oko Bosne i Hercegovine ona nastavlja svoju dvojnu diplomatsku aktivnost u Istanbulu i glavnim gradovima velikih sila da bi osigurala zajam za izgradnju željeznice. ${ }^{79}$ Tijekom studenoga 1908. obavljene su pripreme za osnivanje sindikata koji podupiru vlade Rusije, Francuske, Italije i Srbije. Glavni zadatak toga sindikata bila bi realizacija srpske željeznice Dunav - Jadran. Pregovori koji su o tome vođeni u Rimu završili su krajem studenoga 1908., kada se jamčila proporcionalna kamata od 3,5 \% investicijskoga kapitala od 68 milijuna franaka. Također je odlučeno da će željeznica biti pod upravom međunarodnoga sindikata u nadi da će to utjecati na Istanbul da brže dodijeli koncesiju. ${ }^{80}$ Nakon zajedničkih pritisaka talijanske, ruske, francuske i srpske diplomacije, a i francuskoga dioničkog društva Jonction Salonique-Constantinople, koje je bilo zaduženo za realizaciju željezničkih radova, Porta je napokon popustila, pa je u rujnu 1909. francuskom dioničkom društvu dano dopuštenje za preliminarno sondiranje. U listopadu iste godine stigli su francuski inženjeri da bi počeli trasiranje željezničke pruge. Međutim, na terenu su naišli na neprijateljski raspoloženo albansko stanovništvo Kosovskoga vilajeta, pa su sredinom prosinca 1909. bili prisiljeni zaustaviti rad i vratiti se u Istanbul. ${ }^{81}$ Time su radovi na izgradnji jadranske željeznice ponovo došli na nultu točku.

\footnotetext{
78 BDOW-V-XXXIX, No. 255, Sir G. Lowther to Sir Edward Grey, Therapia, August 10, 1908.

79 Isto.

80 BDOW-V-XXXIX, No. 257, Sir A. Nicolson to Sir Edward Grey, St. Petersburgh, November $27,1908$.

81 МИКИЋ, „Питање трасирања санцачке и јадранске железнице”, 106.
} 
I tijekom 1910. srpska vlada nastavlja napore za dobivanje koncesije od Porte, ali ni potpora Francuske, Italije i Rusije ni posjet srpskoga kralja i premijera Istanbulu nisu dali neki konkretan rezultat. ${ }^{82}$ Albanski ustanak na Kosovu 1910. za autonomiju Albanije još je više zakomplicirao mogućnost realizacije srpskoga željezničkog projekta jer je tijekom proljeća i ljeta iste godine na području odakle je trebala poći željeznička pruga bilo jakih sukoba između albanskih pobunjeničkih snaga i osmanske vojske. Međutim, kako nas obavještavaju talijanski diplomatski izvori, srpska vlada nije isključila mogućnost budućega sporazuma s Albancima za izgradnju puta do Jadranskoga mora. ${ }^{83}$

Njemačka, koja nikada nije odobrila srpski projekt kao takav, sada podržava novu verziju toga projekta, varijantu koju su predložili Porta i osmanski vojni krugovi. To je bila tzv. Južna trasa, koja bi išla linijom Skopje - Gostivar - Debar - Šenđin. No vlada Srbije kategorički odbacuje taj novi prijedlog. Srbe je poduprlo i Francusko društvo za izgradnju željeznica, koje je podržavalo srpsku, tzv. Sjevernu trasu, koja bi išla linijom Merdare - Prizren - Šenđin. ${ }^{84}$

Početkom 1911. zbog teške financijske situacije Porta je bila prisiljena potražiti pomoć stranoga financijskoga kapitala. To je bio dobar signal za Beograd jer se znalo da će Porta najprije pokucati na vrata Francuske, čiji je financijski kapital bio prilično prisutan u Osmanskom Carstvu. To se i dogodilo, pa su srpski diplomati u Parizu i Rimu dobili instrukcije od svoje vlade neka uvjere francusku vladu da bi zajam potreban Porti trebao biti uvjetovan sine qua non dopuštenjem izgradnje srpske jadranske željeznice. ${ }^{85} \mathrm{U}$ tim okolnostima činilo se da je koncesija za srpsku jadransku željeznicu nadomak ruke. Konačno, nakon intenzivnih pregovora o spomenutim prijedlozima, 29. srpnja 1911. potpisan je sporazum između Porte i dioničkoga željezničkog društva Régie Générale des Chemins de Fer u Istanbulu. Odlučeno je da se izgradi „Južna trasa”, ali uz neke ispravke - ruta će ići od Prizrena preko Debra i doline Meče do Šenđina, a radovi trebaju biti dovršeni u roku od šesnaest mjeseci. ${ }^{86}$

Kada su se sve prepreke činile prevladane, u rujnu 1911. izbio je Talijansko-turski rat u Libiji, što je ponovo spriječilo početak radova. U proljeće 1912. pokušalo se prethodno dogovoreni sporazum provesti u praksi, ali kada je u Prištinu stigla komisija inženjera za trasiranje, izbija novi albanski ustanak za autonomiju, koji se u kratkom vremenu proširio na sve vilajete gdje su Albanci

82 ЂОРЂЕВИЋ, „Пројект Јадранске железнице”, 30.

83 ASD-MDAE-DD, Quarta Serie: 1908-1914, Volume V-VI, d. 720, Il Ministro degli Esteri, Di San Giuliano, alle ambasciate a Berlino, Constantinopoli, Londra, Parigi, Pietroburgo e Vienna e alle legazioni a Belgrado, Cettigne e Sofia, T. 614, Roma, 17 febbraio 1911.

84 ЂОРЂЕВИЋ, „Пројект Јадранске железнице”, 31.

${ }^{85}$ ASD-MDAE-DD, Quarta Serie: 1908-1914, Volume V-VI, d. 724, l' Addetto Militare a Sofia, Merrione, al Capo di Stato Maggiore dell'Esercito, Pollio, Sofia, 18 febbraio 1911.

86 Isto. 
bili većinsko stanovništvo. Tako je 19. svibnja 1912. inženjerska komisija opet morala prekinuti radove, pokupiti alat i stručne instrumente i vratiti se u Istanbul. $^{87}$

Diplomatska kriza zbog srpskoga okupiranja albanskih luka

Događaji koji će uslijediti nakon izbijanja Prvoga balkanskog rata u listopadu 1912. stvorili su potpuno nove okolnosti na ovom dijelu Balkana. Projekt srpske jadranske željeznice nije se mogao ostvariti u mirnim okolnostima, ali sada, u ratnima, Srbija ga dobiva priliku ostvariti snagom oružja. Za dva tjedna srpska i crnogorska vojska uspjele su bez većega napora okupirati Kosovo, pretežno zbog sabotaže čelnika turske vojske. Nedugo nakon toga, 9. i 10. studenog 1912. srpska vojska kreće prema albanskom primorju iz dva smjera: iz Đakovice (Drinska divizija) i Prizrena (Šumadijska divizija). Prolazeći dolinom Drima, srpska vojska okupira Ljumu, Mirditu i Mat, a 18. studenog stiže u Lješ. Sljedećega dana zajedno s crnogorskom vojskom okupira Šenđin. Dio srpske vojske potom kreće prema Draču, a neki su odredi krenuli na sjever da pomognu Crnogorcima u osvajanju Skadra. Na putu za Drač srpska vojska okupira Kruju i Tiranu, a 29. studenog, dan nakon što su Albanci proglasili neovisnost u Vlori, okupira i Drač. Sada su u rukama Srbije dvije važne pomorske luke, Šenđin i Drač. Međutim, izlazak Srbije na Jadransko more preko albanskih luka nisu odobrile europske sile. U tim okolnostima stav AustroUgarske i Italije bio je krucijalan za suprotstavljanje uspostavi Srbije ili bilo koje druge države na jadranskoj ili jonskoj obali. Osim diplomatskih sredstava, Ballhausplatz nije isključio ni upotrebu ekstremnijih mjera. Odmah nakon otvaranja jadranske krize austrougarska vlada odlučno istupa sa stavom da je „minimalni austrijski zahtjev da Albanija ostane autonomna ili neovisna država i da nijedan dio jadranske obale neće postati dio Srbije". ${ }^{88}$ Takav odlučan stav Beča uglavnom se temeljio na činjenici da bi teritorijalni izlazak Srbije na Jadran ugrozio ne samo političke i strateške nego i ekonomske interese AustroUgarske. Ekonomska neovisnost Srbije nesumnjivo bi bila na štetu austrijske industrije i vanjske trgovine na Balkanu, a računalo se i s tim da bi srpska luka lako mogla postati ruska vojna baza na Jadranu. ${ }^{89}$ No, stav Njemačke o tom pitanju bio je iznimno važan za Austro-Ugarsku. Berlin je rješenje vidio u izlasku Srbije na Egejsko more, iako su se očekivali snažni prigovori Bugarske i Grčke. ${ }^{90}$ Italija se kao saveznica Austro-Ugarske isto tako kategorički protivila

${ }^{87}$ Isto. - Srpski projekt željeznice djelomično je realiziran samo na liniji Prahovo - Zaječar, koja je počela s radom u lipnju 1914. godine. Zaječarsko-knjaževačka linija završena je u siječnju 1915. godine. Austrijski projekt nije započeo sve do Prvoga svjetskog rata (MARIĆ, STOŠIĆ, Srbija 1914, 11).

${ }_{88}$ TNA-PRO-FO, 424/235, No. 232, Sir F. Cartwright to Sir Edward Grey, Vienna, November 7, 1912 .

${ }^{89}$ DILO, „Çështja shqiptare”, 208.

${ }_{90}$ TNA-PRO-FO, 424/235, No. 120, Sir E. Goschen to Sir Edward Grey, Berlin, November 4, 1912. „Servia should have access to the Ægean Sea rather than through Albania to Adriatic, as it 
teritorijalnom širenju Srbije na albanske obale Jadrana. Talijanska je vlada 8. studenog 1912. prenijela u Sankt Peterburgu sljedeće:

1) srpski zahtjev je kršenje nacionalnoga načela na kojem se temelji opće rješenje balkanskih pitanja

2) ovaj zahtjev Srbije šteti autonomiji ili neovisnosti Albanije, za koju su angažirane Austro-Ugarska i Italija

3) ovaj zahtjev potaknut će albansko-srpsko neprijateljstvo i izazivati neprekidne nemire i ustanke, što bi bilo iznimno opasno za održavanje mira Srba

4) Austro-Ugarska je pokazala veliku spremnost da prihvati druge zahtjeve

5) Srbija može naći i drugi izlaz na more, ne nužno na Jadran. ${ }^{91}$

Talijanski ministar vanjskih poslova San Giuliano 12. studenog 1912. izrazio je svoj stav srpskom diplomatskom predstavniku u Rimu. Zatražio je od srpske strane da što prije odbaci ideju o luci na albanskoj obali. Srpska luka na albanskoj obali, prema riječima talijanskoga ministra, bila je u koliziji s talijanskim interesima. Ta luka „onemogućila bi postojanje autonomne ili neovisne albanske države, kršeći tako etničko načelo na kojem se temelji svako rješenje". ${ }^{92}$

Nade srpske vlade da će njezin zahtjev za teritorijalno proširenje na Jadran dobiti potporu u Londonu i Parizu bile su neutemeljene. Britanska vlada, iako je isticala određenu naklonost balkanskim saveznicima, nije mogla poduprijeti takav ekspanzionistički zahtjev, koji je bio ne samo nerealan nego i u suprotnosti s britanskom istočnom politikom..$^{93}$ Čak i francuska vlada, unatoč simpatijama koje je imala prema Srbiji, upozorava Beograd od samoga početka te diplomatske krize da nipošto ne namjerava ratovati zbog srpske luke na Jadranu. Štoviše, sile Antante bile su uvjerene da je Austro-Ugarska zbog toga pitanja spremna i zaratiti. ${ }^{94}$ Rusija je bila jedina sila koja je na početku krize bila spremna poduprijeti i opravdati zahtjev Srbije da dobije teritorijalni izlaz na jadransku obalu. Međutim, ruska vlada nije naišla na potporu Londona i Pariza. Upravo te dvije velike sile vrše snažan pritisak na Sankt Peterburg da povuče svoju potporu srpskim zahtjevima, osobito nakon ozbiljne prijetnje rata Austro-Ugarske protiv Srbije. Nakon što je kriza poprimila zabrinjavajuće razmjere Rusija je bila prisiljena povući se. Srbija je ostala bez ruske potpore, čak i bez potpore balkanskih saveznica Grčke i Bugarske, pa je morala odustati

would suit Austria-Hungary better" (Isto); No. 192, Sir E. Goschen to Sir Edward Grey, Berlin, November 6, 1912; No. 254, Sir E. Goschen to Sir Edward Grey, Berlin, November 8, 1912.

91 TNA-PRO-FO, 424/235, No. 263, Sir Edward Grey to Sir R. Rodd, Foreign Office, November 8,1912 .

92 TNA-PRO-FO, 424/235, No. 362, Sir Edward Grey to Sir R. Rodd, Foreign Office, November $12,1912$.

93 TNA-PRO-FO, 424/235, No. 258, Sir Edward Grey to Sir E. Goschen, Foreign Office, November $8,1912$.

94 TNA-PRO-FO, 424/235, No. 299, Sir R. Rodd to Sir Edward Grey, Rome, November 9 , 1912. 
od svoje jadranske politike. Vlada Srbije 19. prosinca 1912., trećega dana zasjedanja Londonske konferencije veleposlanika, upućuje velikim silama notu u kojoj, među ostalim, stoji:

„Imajući u vidu položaj Austro-Ugarske, koja je izjavila da neće dopustiti da Srbija nasilno drži okupiranu obalu; i želeći živjeti u miru sa njenim susjedom - srpska vlada smatra da su uvjeti zreli za rješavanje spornih pitanja. Koristeći priliku saziva Konferencije veleposlanika u Londonu, srbijanska vlada želi da velikim silama povjeri rješavanje pitanja izlaska Srbije na Jadran preko teritorija pod njenim suverenitetom. Vlada Srbije poziva velike sile da u ovom slučaju uzmu u obzir velike žrtve koje je Srbija dala za osiguranje svoje političke i ekonomske neovisnosti." ${ }^{95}$

Zapravo će postavljanje modaliteta za prihvatljivo rješenje pitanja trgovačkoga izlaza Srbije na Jadran preko željeznice preuzeti na sebe Londonska konferencija veleposlanika, ali to će pasti u sjenu mnogo važnijih pitanja s kojima će se suočiti veleposlanici velikih sila u Londonu tijekom idućih mjeseci 1913. godine.

U vrijeme jadranske krize srpska vlada intenzivno je razvijala diplomatsku propagandu, inzistirajući na tome da Srbija bez teritorijalnoga izlaska na more ne može opstati kao država. ${ }^{96}$ Zahtjev za izlazak na more opravdavala je i činjenicom da je prije mnogo godina bila prisiljena prihvatiti austrijsku okupaciju Bosne i Hercegovine, pa sada traži odštetu na albanskom tlu. ${ }^{97}$ Takvu politiku srpske vlade Dimitrije Tucović ovako komentira:

„U slatkom zanosu da drži u svojoj ruci naoružanu celu zemlju, buržoazija je u rastočavanju narodne snage otišla preko svih granica mogućnosti i počinila najluđe zloupotrebe. Vrhunac tih zloupotreba je pokušaj izlaska na more putem zavojevanja Arbanije. Za izlazak na more Srbija je imala dva prirodna pravca. Prvi preko Crne Gore za Bar [...] drugi, vardarskom dolinom za Solun, [...] saobraćajnom arterijom koja je samom prirodom određena da bude glavni pravac privredne veze Balkanskoga Poluostrva sa svetom. [...] Namesto da traži izlazak na more u ovim prirodnim pravcima, za šta je bilo potrebno biti rešen na sistematsku i odlučnu borbu protiv separatističkih težnja, vlada je separatizam uzela za osnovicu ugovora sa saveznicima. Time je buržoazija sama sebi zatvorila oba prirodna pravca za izlazak na more. A odričući se njih ona se otiskuje da put na more probije kroz arbanske krševe, pravcem koji vodi preko oblasti sa kompaktnim tuđim elementom, elementom najveće otporne snage $\mathrm{u}$ pređašnjoj Evropskoj Turskoj. [...] Bilo da Srbija dobije samo prugu bilo i jedan

95 ПОПОВИЋ, Борба за народно уједињење, 103-104.

96 TNA-PRO-FO, 424/235, No. 204, Sir Edward Grey to Sir E. Goschen, Foreign Office, November 6,1912. „The Servian chargé d'affaires had just come to see me, and had said that this access was a matter of life and death to Servia. Nothing was worth anything to her without the economic independence for which a port on the Adriatic was essential, and the Servians would fight to the end to obtain such a port." ASD-MDAE-DD, A stampa I, DDC, Serie XXII - Serbia, 1912 [7], Incaricato d'affari in Belgrado al Ministro degli affari esteri, N. 1243/231, Belgrado, 7 novembre 1912.

97 AIHGJ, Lidhja II - Probleme Ballkanike, 71. 
širi ili uži pojas zemlje, održavanje arbanaskoga stanovništva u pokornosti bilo bi skopčano sa žrtvama za koje bi se dobar trgovac teško odlučio. Što god bi taj pojas zemlje bio širi, u toliko bi i žrtve bile veće." ${ }^{\prime 8}$

Ukratko, izlazak Srbije na more preko albanskoga teritorija Tucović je okarakterizirao kao politički apsurd (ropstvo albanskoga stanovništva), ali i ekonomski apsurd (veći troškovi od samih ekonomskih plodova). ${ }^{99}$ George F. Williams srpske pretenzije u Albaniji sažima u jednoj rečenici: „Dok kritizira Austro-Ugarsku zbog aneksije Bosne i Hercegovine, [Srbija] bez srama traži teritorijalni izlazak na more kroz albanski teritorij."

\section{Zaključak}

Iz ovoga rada zaključujemo da su projekti o izgradnji transbalkanskih željeznica imali formalno ekonomski karakter, ali su suštinski odražavali ambicije velikih sila i mladih balkanskih monarhija da preko svojih željeznica uspostave interesne sfere, čime bi dobile prednosti nakon očekivanoga raspada Osmanskoga Carstva. Kao što je pokazano, za gotovo sve predložene željezničke projekte velikih sila i balkanskih monarhija planiran je prelazak preko albanskih teritorija, a da pritom nitko nije uzeo u obzir mišljenje Albanaca i njihove stvarne potrebe. Između 1908. i 1912. Albanci su bili suočeni s jedne strane s antialbanskom vladavinom mladoturaka, a s druge strane s ekspanzionističkim planovima susjednih monarhija, koji su do početka balkanskih ratova testirani upravo preko željezničkih projekata. Stoga nije slučajnost što su Albanci s posebnim nepovjerenjem gledali na svaku aktivnost vezanu za izgradnju željezničkih pruga koje su namjeravale proći kroz njihovu zemlju. Početak balkanskih ratova rezultirao je okupacijom Albanije od Balkanske alijanse, no Austro-Ugarska i Italija, unatoč suparništvu na ovom dijelu Balkana, uspjele su 1912. spriječiti teritorijalni izlazak Srbije na albansko primorje, ali po cijenu žrtvovanja Kosova i albanskoga dijela Makedonije na Konferenciji veleposlanika u Londonu.

98 ТУЦОВИЋ, Сабрана дела, knj. 7, 89-90.

99 Isto.

${ }^{100}$ WILLIAMS, Shqiptarët, 31. 


\section{Arhivski izvori}

AIHGJ: Arkivi i Institutit të Historisë dhe Gjuhësisë, Tiranë, fond Lidhja II - Probleme Ballkanike.

ASD-MDAE-DD: Archivio Storico Diplomatico, Ministero Degli Affari Esteri, Roma, fond Documenti Diplomatici.

BM-BL-AAP: British Museum - British Library, London, State Papers Room, Accounts and Papers (56) 1909. CV. 105, fond Turkey, No. 1 (1909) Correspondence respecting the Constitutional Movement in Turkey, 1908.

TNA-PRO-FO: The National Archives of the UK, Public Record Office, Foreign Office, London, fond 424/235; fond BD 1898-1914, Vol. V, 01968; fond BDOW, Vol. V, 01969.

\section{Objavljeni izvori}

BDOW-V-XXXIX: British Documents on the Origins of the War 18981914, Vol. V, The Near East, Chapter XXXIX - The Dispute About the Adriatic and Novibazar Railways, 1906-8.

\section{Literatura}

чУБРИЛОВИТ, Васа. Историја политичке мисли у Србији ХІХ века. Београд: Народна књига, 1958.

DILO, Timo. „Çështja shqiptare në Konferencën e Ambasadorëve në Londër”. U: Mbi Lëvizjen Kombëtare Shqiptare, red. Stefanaq Pollo. Tiranë: Universiteti Shtetëror i Tiranës, Instituti i Historisë e Gjuhësisë, 1962, 206-264.

ЂОРТЕВИЋ, Димитрије. „Пројект Јадранске железнице у Србији 1896-1912". Историјски гласник (1956), br. 3-4, 3-49.

ЂОРЋЕВИЋ, Димитрије. „Србија и Балкан на почетку ХХ века (1903-1906)". U: Југословенски народи пред Први светски рат, ур. Baса Чубриловић. Београд: Научно дело, 1967, 207-230.

ĐURANOVIĆ, Šarlota. Opća povijest 1870-1918. Zagreb: Školska knjiga, 1957.

GLENNY, Misha. The Balkans: Nationalism, War, and the Great Powers, 1804-1999. London: Granta Books, 2000.

GOSTENTSCHNING, Kurt. „Qëndrimet e Austro-Hungarisë ndaj Lëvizjes Kombëtare Shqiptare në kontekstin e marrëdhënieve të përgjithshme austro-shqiptare". U: Shqipëri-Austri Reflektim historiografik, red. Ardian Marashi \& Albert Rakipi. Tiranë: Qendra e Studimeve Albanologike; Instituti Shqiptar për Studime Ndërkombëtare, 2013, 39-47.

ЈАКШИЋ, Гргур; ВУЧКОВИЋ, Војислав Ј. Спољна политика Србије за владе кнеза Михајла (први балкански савез). Београд: Историјски институт, 1963. 
JELAVICH, Charles; JELAVICH, Barbara. Themelimi i shteteve kombëtare të Ballkanit 1804-1920. Tiranë: Dituria, 2004.

KANN, Robert A. A History of the Habsburg Empire 1526-1918. Berkeley; Los Angeles; London: University of California Press, 1977.

MARIĆ, Mihajlo; STOŠIĆ, Branko. Srbija 1914. Beograd: Sedma sila, 1965.

MICHON, Georges. The Franco-Russian Alliance 1891-1917. New York: Howard Fertig, 1969.

МИКИЋ, Ћорће. „Питане трасирана саниачке и јадранскежелезнице кроз Косовски вилајет 1908/9. године”. Обележја III (1976).

ПЕРОВИЋ, Бранко, ur. Први балкански рат 1912-1913 (операције српске војске), knj. I. Београд: Историјски институт Југословенске народне армије, 1959.

ПОПОВИЋ, Димитрије. Борба за народно уједињење 1908-1914. Београд: ИКП Геца Кон А. Д., 1914.

РАТКОВИЋ, Борислав; ЂУРИШИЋ, Митар; СКОКО, Саво. Србија и Црна Гора у Балканским ратовима 1912-1913. Београд: БИГЗ, 1972.

RICH, Norman. Diplomacia e Fuqive të Mëdha 1814-1914. Tiranë: TOENA; Instituti i Dialogut dhe i Komunikimit, 2006.

СКОКО, Саво. Други балкански рат 1913, knj. I: Узроци и припреме рата. Београд: Војноисторијски институт, 1968.

SHAW, Stanford J.; SHAW, Ezel Kural. Historia e Perandorisë Osmane dhe e Turqisë Moderne, sv. 2. Tiranë: Jehona Study Center, 2016.

ŠIŠIĆ, Ferdo. Predratna politika Italije i postanak Londonskog pakta (18701915). Split: 1933., knj. 7. Прир. Младен Вукомановић. Београд: Рад, 1980.

WILLIAMS, George Fred. Shqiptarët. Tiranë: Dielli, 1934.

\section{Internetski izvori}

DZHALEVA-CHOKOVA, Anna. „Balkans Railways Development: Contradictions in the Past, Cooperation at Present". Mechanics Transport Communications, issue 3 (2007), article No. 0197. Pristup ostvaren 10. 4. 2019. http:// www.mtc-aj.com.

ELSIE, Robert. Early Photography in Albania. Die Fotosammlung des Alexandre Baschmakoff. Montenegro, Nordalbanien und Kosovo im Jahre 1908. Pristup ostvaren 15. 3. 2019. http://www.albanianphotography.net/baschmakoff/index.html.

„Uvac, Rudo”. Wikipedia. Pristup ostvaren 8. 3. 2019. https://en.wikipedia. org/wiki/Uvac,_Rudo. 


\section{SUMMARY}

\section{Diplomatic Disputes regarding the Trans-Balkan Railway Projects in the 1900-1912 Period in the Context of the Albanian Question}

This article offers a view from a diplomatic standpoint on the rivalry and disputes between the great powers and the newly-established Balkan states regarding the trans-Balkan railway projects in the 1900-1912 period. It is based mostly on archival material of a diplomatic provenance. Economic and geostrategic issues have always been closely linked. In the context of the Balkans, these issues became more important in the early $20^{\text {th }}$ century, when a clash of economic, political, and strategic interests took place between the great powers and the new Balkan states. The ideas and projects of building trans-Balkan railways were created in the late $19^{\text {th }}$ and early $20^{\text {th }}$ centuries, mostly within the frame of Austria-Hungary, Italy, Serbia, Montenegro, Bulgaria, and Greece, but the Ottoman Empire and other European powers also became involved in the matter. Although these states cited economic interests, the Sublime Porte, which was responsible for issuing building concessions, was convinced that political and strategic goals stood behind these railway projects, and therefore hesitated for several years. A diplomatic discourse on the Balkan railways developed in the 1906-1912 period, primarily between Austria-Hungary and Serbia. However, these projects remained only on paper due to sudden political upheavals in the Balkans in the 1908-1912 period, and particularly due to the diplomatic crisis that took place between Austria-Hungary and Serbia, related to Serbia's attempts to secure access to the Adriatic via the Albanian littoral.

Key words: Austria-Hungary; Balkan railway projects; great powers; Adriatic Sea; Shëngjin; Serbia 